\title{
The Implementation of Islamic Financial Literacy Through "Kencleng" Program in School
}

\author{
lis Aisyah and Dadang Saepuloh
}

Pendidikan Ekonomi, FKIP, Universitas Islam Syekh-Yusuf Tangerang

\section{Abstract}

Islamic financial literacy consists of 3 aspects, namely basic money management, financial planning, charity donation and zakat. One aspect of financial literacy is charity donation consisting of waqaf and sadaqah (alms). Islamic finance literacy is important to be understood and applied early so that students understand about the management of Islamic finance and has the characteristics of Muslims. Application of Islamic financial literacy in schools can be applied one of them through the activity called "kencleng". The purpose of this study is to describe the implementation of Islamic financial literacy, especially about alms through the program "kencleng" in schools, as well as one application of character education for students. This kencleng program is done in SMK Lab School Tangerang. The method used is descriptive method. The results of this study indicate that most students have the level of understanding of Islamic financial literacy in the medium category that is equal to $81 \%$. Behavior of charity "kencleng" as my students is $63 \%$ or in fairly good category. It means the student who has good Islamic financial literacy has good enough behavior of alms "kencleng" also in. Thus, this "kencleng" program becomes an alternative to the application of Islamic financial literacy for students.

Publishing services provided by Knowledge E

(c) lis Aisyah and Dadang Keywords: islamic financial literacy, alms (kencleng)

Saepuloh. This article is

distributed under the terms of the Creative Commons

Attribution License, which permits unrestricted use and redistribution provided that the original author and source are credited.

Selection and Peer-review under the responsibility of the ICIEBP Conference Committee.

\section{Introduction}

Financial literacy is the ability or knowledge to manage finances. This is as stated by Miller, et. al. (M. Azmi Abdulloh, et. al. 2017:67) financial literacy is very essensial as an access of financing to create insentive and environtment that embodies disired financial behavior, such as saving, budgeting, or using credit wisely. Along with the development of tyhe concept of islamic economics, there are several things in the field of literacy, one of them is Islamic financial literacy concept.

Islamic financial literacy is the way of managing finance (income and expenses) as a Muslim, financial literacy is not only limited to the basic things, including the understanding of zakat, infaq, charity. As stated by M. Azmi Abdullah et. al (2017-69) 
islamic financial literacy can be defined as the ability to understand finance based on the syariah compliance.

One part of the understanding of islamic financial literacy is charity (alms). Charity comes from the word sadaqa which means true. People who like to give charity can be interpreted as people who are true to their faith. According to the term or terminology of syariah, charity is to give a portion of assets or income for an interest that is ordered by religion. Charity is also a gift that is issued voluntarily to anyone, without nisab and without the excistence of binding time rule (Muhamad Sanusi, 2009: 8-9).

The concept of charity and its use is not only in society, but also at the school level. Beside to growing the financial literary of students, it is also to make the students to have the character and behavior of helping each other.

There are several applications of islamic financial literacy, one of them is through charity activities at school. In SMK Labschool Tangerang, the implementation of islamic financial literacy is carried out through the activity of "kencleng" at school every week. "Kencleng" in Indonesia is a simple of language term of a place to save money with oval-shaped tin so that when the coin is inserted it will sound "kencreng".

The islamic financial literacy which based on compliance with islamic law will also be influenced by the beliefs and views of individual in their religion. As stated by Lusardi et. al (2009), younger generation has a low input in financial literacy, as indicated by th strong relationship between socio-demographic characters and family financial shopistication.

Based on the statement above, financial literacy can be influenced by sociodemography. Socio-demography consist of gender, region, culture, and environment. kencleng activity as one of the activities in the school envireonment is expected to be one of the programs that can improve students' islamic financial literacy. Because basically, financial literacy has two aspects. The concept of financial literacy according to Huston $(2010 ; 306)$ has two dimentions, they are understanding (personal financial knowledge) and use (the application of personal financial). According to the first data, the activity of kencleng at school stated about motivation and their understanding related to the "kencleng" program.

The students' views on the kencleng program in school mostly state that when they fill in the kencleng is based on religious beliefs, while as many as 30\% students state their views when filling in the kencleng at school is just because of the program's obligation from school. Based on the data obtained that islamic financial literacy is still in the level of kencleng program which is initiated by the school, so there must be an improvement effort. This is to educate the students to be able to manage finances, to 
TABLE 1: Kencleng Program on the Students' Side.

The students' view about
Kencleng Program
The duty from school
Charity/religious belief
others

$\begin{gathered}\text { Frequency } \\ \text { (person) }\end{gathered}$
9
18
3

Percentage (\%)

30,00

60,00

10,00

be not consumptive, rational and socially provide the application of islamic financial literacy in relation to decision.

The "kencleng" program at school has a social purpose which is to help students who are lack in funding. Rob and Sharpe (2009) explained that high balances might be the result of low levels of financial assistance, using credit card as the alternative of school funding. So that, the expectation in an early age is not only to fostering mutual help, but also to train the islamic financial literacy of students. Thus, the financial literacy is important to be early implemented, especially in the learning process at school. The writer is interested to discuss the implementation of islamic financial literacy through "kencleng" program to improve the values and characteristics of Islam.

This study is going to discuss: How does the implementation of the "kencleng" program be implemented? What is the coleration between the "kencleng" program and the understanding of students' islamic financial literacy?

\section{Theoritical Review}

\subsection{Islamic financial literacy}

According to Financial Services Authority (2013) defines financial literacy as a series of processes or activities to increase knowledge; conidence; and skill; consumer and the wider community so that they are able to manage finances better. Financial literacy as the ability to understand the financial conditions and change them into behavior. These behaviors is in order to saving wealth, consist of consumption, savings, investment, and loans.

Financial literacy is very important to be taught in the early so that in the future they will be more rational and are able to make financial decision wisely. The main object of the National Financial Literacy Strategy is to realize Indonesian people who have a high financial literacy level (well literate) so that people can choose and utilize financial products and services to improve welfare. As the result of the research of Eitel 
and Martin (2009) explain financial literacy is very important for the success of future generations. Lusardi (2003) states that financial literacy is an important skill forr decision making and welfare during life cycle. Financial literacy has been defined as the ability to make information assessment and to take efeective actions regarding current and future use and money management (US Dept of Treasury, 2008).

Indonesia has the potential for the development of islamic literacy. In the assessment of Global Islamic Financial Report (GIFR) in 2011, Indonesia is in the position of fourth country which has potential and conducive condition in the development of islamic financial industry after Iran, Malaysia, and Saudi Arabia. Preference on Islamic finance which becomes the concern of Kunt, Klapper and Randall (2013), classifies Muslim into three categories in accordance to their preferences between islamic finance and conventional.

According to M. Azmi Abdullah et.al (2017:69) most of findings show that the conceptual definition of financial literacy falls into five categories, as follows:

1. Knowledge about financial concepts;

2. The abillity to communicate about financial concepts;

3. Skill in managing personal finances;

4. Skill in making right financial decision; and

5. the belief in planning effectively for future financial needs.

Islamic financial literacy can be defined as the ability to understand finance according to syariah compliance. This should be a matter of concern for Muslim students. Muslim must try to understand islamic finance because it has been regulated in religion. Aperson's ability in using finacial knowledge, skill and attitude in regulating finacial resources based on islam. (OECD, 2012). According to Abdullah, Rose, and Ahmad Luthfi Haji AR. (2015:65) islamic financial literacy consists of three aspects, as follows:

1. basic money/wealth management (earning halal, consumption, saving)

2. financial planning (insurance, islamic invesment, pension shemes)

3. alms/charity donation (waqf and sadaqah)

4. zakat, law of inheritance (faraid) and wasiyah

The results of the study (Arum Setyowati, et.al.:70) shows that (1) the IFL level in Solo is 64,66\%; (2) people with good IFL level will be better in managing their personla finances; (3) people with good IFL level will prefer to invest in islamic assets. 
Daniel Shephard's research result (2015) state that teachers throught active learning with RCT method try to apply financial Iliteracy. The result obtained were that students were more solid and bonded, more empowered in term of financial literacy, planing attitude, saving attitude and saving behavior.

Any text or material outside the aforementioned margins will not be printed.

\subsection{Alms (Kencleng)}

Alms/charity is derived from th word shadaqoh which means a gift given by a muslim to others spontaneously and voluntarily without being limited by time and a certain amount. Charity means a gift given by someone as a virtue that expects Allah's blessing and merit only. (Aqilah Selma Amalia, 2014: 140).

In indonesia as a Muslim-majority country in charity activities, there is something known as kencleng. Kencleng according to Abdul Rahman (2011:29) is a simple term from the word canned "celengan" which is oval-shaped, so that when a coin is inserted it will sound "kencreng". While kencreng itself according to KBBI is a clone of the sound of coins dropped into a can. The purpose of kencleng is to ease students/individual in charity and to increase awareness of individual towards charity and infaq

\section{Methodology}

This study would use the descriptive methodology and employed 105 respondents. The sample is students at SMK Lab Business School Syekh-Yusuf Tangerang. The measurement of Islamic financial literacy will be tested and validated. The measure is based on three aspects: namely basic money management, financial planning, charity donation and zakat. Islamic Financial Literacy will be measured using true/false test question.

\section{Finding and Discussion}

Based on the findings of questionnaire that had been distributed to 150 students of SMK Lab Business School Syekh Yusuf which consisted of 11 items to measure Islamic Finance Literacy and 11 items to measure Kencleng program at school.

Tabel 2 shows that the students' Islamic Finance Literacy is at moderate category. Meanwhile, the category of literacy of Islamic Finance based on gender is displayed on table 3. 
TABLE 2: Students' Islamic Financial Literacy.

\begin{tabular}{l|c|c|}
\hline Category & $\begin{array}{c}\text { Frequency } \\
\text { (person) }\end{array}$ & Percentage (\%) \\
\hline$>8$ (high) & 18 & 17,00 \\
\hline $4-8$ (moderate) & 85 & 81,00 \\
\hline$<4$ (low) & 2 & 2,00 \\
\hline
\end{tabular}

TABLE 3: Data Tabulation of Islamic Finance Literacy based on Gender .

\begin{tabular}{|l|c|}
\hline Gender & Low \\
\hline Female & 1 \\
\hline Male & 1 \\
\hline Total & 2 \\
\hline
\end{tabular}

\begin{tabular}{|c|c|}
\hline Moderate & High \\
\hline 45 & 14 \\
\hline 40 & 4 \\
\hline 85 & 18 \\
\hline
\end{tabular}

Table 3 indicates that females have higher Islamic Finance Literacy than males. The applied instrument to measure students' Islamic Finance Literacy can be analyzed by students' answer on each question item.

The table above points that the category of Kencleng program implementation at school according to students are at fair and good category. The statements asked to them on kencleng implementation directed the students to their perspective and observation about the implementation and purposes or kencleng program.

The students in this Kencleng program were habituated to give charity every week without specific amount to mention. In this activity, one of the advantages is creating generosity, helping each other and training students' finance literacy in terms of pocket money management charity using kencleng.

Through this activity, the funds are allocated to daily charity activity or Friday charity, social charity, and social activity, and also helping tuition fee for the students in need from the kencleng funds. Therefore, moslem character education can be created among the students.

Character education is a national movement that was initiated by the school to develop ethics, responsibility and to guard the youths by learning modeling and by good characters through the highlight of shared universal values. According to Maragustam Siregar (2015: 254). Character education is creating and internalizing values on students through education, experience, habituation, rules and crafted environment.

By kencleng program at school, it is expected that not only for the internalization character education, the program also internalize the Islamic Finance Literacy which the components are not limited only to cognitive aspects but also to the implementation. 
TABLE 4: The Description of Students' Answer on Islamic Financial Literacy.

\begin{tabular}{|c|c|c|c|}
\hline No. & Statement & True & False \\
\hline 1. & $\begin{array}{l}\text { Every person has a budget plan for } \\
\text { their revenues and expenses. }\end{array}$ & $99 \%$ & $1 \%$ \\
\hline 2. & $\begin{array}{l}\text { Buying goods according to the } \\
\text { needs of social groups is not a } \\
\text { personal need. }\end{array}$ & $68 \%$ & $32 \%$ \\
\hline 3. & $\begin{array}{l}\text { Every individual has savings for } \\
\text { precautionary purposes }\end{array}$ & $97 \%$ & $3 \%$ \\
\hline 4. & $\begin{array}{l}\text { Every shortage of money / income } \\
\text { the individual will make a loan to the } \\
\text { bank }\end{array}$ & $55 \%$ & $45 \%$ \\
\hline 5. & $\begin{array}{l}\text { Income zakat must be issued every } \\
\text { month for those who work }\end{array}$ & $76 \%$ & $24 \%$ \\
\hline 6. & $\begin{array}{l}\text { Savings and investments have the } \\
\text { same nature }\end{array}$ & $59 \%$ & $41 \%$ \\
\hline 7. & $\begin{array}{l}\text { The nature and provisions of zakat } \\
\text { are the same as waqf, alms and infaq }\end{array}$ & $73 \%$ & $27 \%$ \\
\hline 8. & $\begin{array}{l}\text { The amount of charity is determined } \\
\text { by the place that receives alms }\end{array}$ & $19 \%$ & $81 \%$ \\
\hline 9. & $\begin{array}{l}\text { Infaq must have fixed assets such as } \\
\text { land, buildings, vehicles, machinery, } \\
\text { etc. }\end{array}$ & $17 \%$ & $83 \%$ \\
\hline 10. & $\begin{array}{l}\text { One example of usury is the interest } \\
\text { set by the Bank to the person } \\
\text { making a bank loan. }\end{array}$ & $80 \%$ & $20 \%$ \\
\hline 11. & $\begin{array}{l}\text { Everyone is required to find income } \\
\text { in the right and lawful way }\end{array}$ & $98 \%$ & $2 \%$ \\
\hline
\end{tabular}

TABLE 5: The Implementation of "kencleng" Program at School.

\begin{tabular}{l|c|c|}
\hline Category & $\begin{array}{c}\text { Frequency } \\
\text { (person) }\end{array}$ & Percentage (\%) \\
\hline$>34$ (Good) & 39 & 37,00 \\
\hline $23-34$ (Fair) & 66 & 63,00 \\
\hline$<23$ (Low) & 0 & 0,00 \\
\hline
\end{tabular}

In line with Walstad et al, (2010) who stated that finance education program in general focuses on teaching students about conventional finance literacy. The students will gain benefits and widen their finance comprehension if the finance education are applied since High School Level. Introducing finance literacy earlier is important in influencing prosperity and individual prosperity management. According to Dhaniel Shephard (2005:3), who stated that finance education should be begun since early 
ages, before the individual bound in a finance contract, so that the finance literacy becomes a guidance in decision making.

Islamic finance perspective is not explicitly written in the curriculum. It needs a training for teachers and all the human sources in the institution. According to Abdul Rahman Nawi, (Abdullah Rose, 2015:76) Islamic Finance Literacy in educational curriculum should include learning at school aspects in saving money and creating students' habit of saving.

Having knowledge and skills in finance literacy by concerning on Islamic finance will offer an incredible assets choice. Islamic finance literacy in finance product should be enhanced, particularly for academicians. (Siti Hafizah Abdul Rahim et al, 2016:33). Huston (2010:309) stated that financial education program has been designed specifically to improve finance literacy which could overcome a finance problem for individual and family.

\section{Conclusion}

Based on the explanation above about Islamic Finance Literacy implementation through kencleng program at school that is held every week, the funds can be used for social and religious activities. Kencleng program at school is giving half of someone's money to others without hoping return deed. It is expected that the program can enhance students' Islamic finance literacy. The findings of this research showed that the implementation of kencleng program is at fair level. Between kencleng program and Islamic finance literacy have a relation, which is one of the efforts to enhance students finance literacy that is not written explicitly in the curriculum is habituations, and one of them is kencleng program.

\section{Acknowledgements}

The authors would like to thank the personnel of SMK Lab Business Syekh Yusuf and Universitas Islam Syekh-Yusuf Tangerang.

\section{References}

[1] Aqilah Selma Amalia. (2014). Kisah Nyata Sukses Membuka Pintu Rezeki Dengan 7 Amal Ajaib. Klaten: Abata Press. 
[2] Daniel Shephard dan Yves Valentin Kaneza. (2015). Financial Education for Children: What Curriculum? Which Methods? A Cluster Randomized Controlled Trial of Social and Financial Education in Rwanda. Paper session. ECER 2015, Education and Transition.

[3] Huston, Sandra J. (2010). Measuring Fianncial Literacy. The Journal of Consumer Affairs, Vol. 44, No. 2, 2010. ISSN 0022-0078.

[4] Kunt, Klapper, Randall. (2013). Islamic Finance and Financial Inclusion Measuring Use of and Demand for Formal Financial Services among Muslim Adults. The World Bank Development Research Group Finance and Private Sector Development Team

[5] Lusardi, A., \& Tufano, P. (2009). Debt literacy, financial experiences, and over indebtedness. CFS Working Paper No. 2009/08, Retrieved from http://nbn-resolving. de/urn:nbn:de:hebis:30-63796

[6] Lusardi, A. dan Olivia S. Mitchell. (2009). Financial Literacy: Evidence and Implications for financial education. TIAA-CREF Institute.

[7] Lusardi, A. (2013). Financial Literacy Around The World (Flat World), Insights: Financial Capability. The George Washington University School Of Business And Director, Global Center For Financial Literacy.

[8] M. Azmi Abdullah, et al. (2017). Factors determining Islamic financial literacy among undergraduates. Journal of Emerging Economies \& Islamic Research 5(2) 2017, 67 -76 .

[9] Muhammad Sanusi. (2009). The Power of Sedekah. Yogyakarta: Pustaka Insan Madani.

[10] Nofiaturrahmah, fifi. (2017). Penanaman Karakter Dermawan Melalui Sedekah. Jurnal Zakat dan Wakaf ZISWAF, Vol. 4, No. 2, Desember 2017

[11] OECD. (2012). Measuring Financial Literacy: Questionnaire and Guidance Notes for Conducting an Internationally Comparable Survey of Financial Literacy. Paris: OECD Publishing.

[12] Rahman, Abdul. (2011). Evaluasi Program Kencleng LAZ Al Madinah Ciledug dalam Pemberdayaan Umat. Skripsi UIN Syarif Hidayatullah: tidak diterbitkan.

[13] Robb, C.A. \& Sharpe, D.L. (2009). Effect of personal financial knowledge on college students' credit card behavior. 20.1 Journal of Financial Counseling and Planning, 25-43.

[14] Setyowati, Arum, \& Harmadi., Sunarjanto. (2018). Jurnal Keuangan dan Perbankan|Keuangan. Vol. 22, No. 1, January 2018: 63-72 ISSN: 2443-2687. 
[15] Siti Hafizah Abdul Rahim. (2017). Islamic Financial Literacy and its Determinants among University Students: An Exploratory Factor Analysis. International Journal of Economics and Financial Issues, 2016, 6(S7) 32-35.

[16] Walstad, W.B., Rebeck, K., \& MacDonald, R.A. (2010). The Effects of Financial Education on the Financial Knowledge of High School Students. Journal of Consumer Affairs, 44(2), 336-357.

[17] Laporan Triwulanan Otoritas Jasa Keuangan Triwulan iii - 2013, www.ojk.go.id 